\title{
Bovine Uterine, Cervical and Ovarian Cytosol Estrogen and Progesterone Receptor Concentrations in Cystic Ovarian Disease
}

\author{
By M. Vesanen
}

Department of Clinical Chemistry, University of Oulu, Finland.

\begin{abstract}
Vesanen, M.: Bovine uterine, cervical and ovarian cytosol estrogen and progesterone receptor concentrations in cystic ovarian disease. Acta vet. scand. 1993, 34, 35-43. - Bovine cytosol estrogen (ERC) and progesterone receptor (PRC) concentrations were measured simultaneously in various regions of the uterus and in ovarian stromal tissue in cows with cystic ovarian disease (follicular cysts), and the concentrations compared with those in animals with normal cycles. In cystic ovarian disease, ERC concentrations in endometrium (550 $\mathrm{fmol} / \mathrm{mg}$ cytosol protein (c.p.)) and in myometrium (405) were significantly higher than in control animals. Very high PRC contents were measured in the endometrium (3115) and myometrium (2761) of cows with cystic ovarian disease. In control animals, PRC concentrations in the endometrium and myometrium were significantly lower than in diseased animals. No statistical differences were observed in ERC or PRC contents between the endometrium and the myometrium in cows with cystic ovarian disease. ERC and PRC concentrations in the uterine cervix and ovaries were low compared to those detected in the uterus. Bovine serum estradiol-17ß concentrations were higher $(\mathrm{p}<0.001)$ in cows with cystic ovarian disease than in control animals in postpartum anestrus or during the normal estrous cycle. Serum sex hormone-binding globulin (SHBG) concentrations were of the same magnitude as in control cows during their estrous cycles. These findings show that long standing low endogenous progesterone and elevated estradiol concentrations in serum are associated with elevated ERC and PRC concentrations in bovine uterus.
\end{abstract}

steroid hormones.

\section{Introduction}

Bovine cystic ovarian disease, characterized by 1 or more large anovulatory follicular cysts in 1 or both ovaries and sometimes by abnormal estrous behavior, is one of the most important causes of infertility in dairy cattle. Ovarian cysts normally are classified into 2 groups, follicular cysts and luteal cysts with the former being the more common. Concentrations of progesterone in serum and milk are low in cows with follicular cysts. Treatment of bovine cystic ovarian disease has been extensively studied (Backstrom et al. 1976, Kesler \& Garverick
1982, Koppinen et al. 1984, Ax et al. 1986), but the endocrine events leading to cystic ovarian disease are not well clarified.

Serum steroid hormone concentrations in bovine cystic ovarian disease have been investigated (Dobson et al. 1977, Brown et al. 1986), but the concentrations of cytosol estrogen and progesterone receptors (ERC and PRC, respectively) have not previously been reported. This pathological state with ovarian follicular cyst formation could be expected to present a model characterized by estradiol excess and progesterone deficiency. It was felt interesting to see wheth- 
er this was really true and to characterize the behaviour of estrogen and progesterone receptors in such an unusual condition. Thus, the present study was designed to clarify the interactions of the steroid hormones with the estrogen and progesterone receptors in cystic ovarian disease for better understanding the endocrinology of bovine reproduction.

In our previous investigations we reported variations in bovine uterine ERC and PRC concentrations and serum steroid hormone and sex hormone binding-globulin (SHBG) contents in the postpartum period and during the estrous cycle (Vesanen et al. 1988, Vesanen et al. 1990, Vesanen et al. 1991) in animals with normal reproductive functions. Uterine ERC and PRC contents as well as serum progesterone, pregnenolone and $5 \alpha$-dihydrotestosterone $(5 \alpha$ DHT) concentrations varied according to the phase of normal estrous cycles, and this earlier data saved as reference for this investigation.

\section{Materials and methods}

\section{Animals and collection of samples}

The animals were Finnish dairy cows delivered to slaughter-houses. They were examined by rectal palpation of the genitalia in order to find the cows with cystic ovarian disease and normal cycling animals. Uterine size and tonus, as well as ovarian findings (cysts, size of follicles and corpus luteum) were noticed. Blood samples were collected from jugular veins without anticoagulant. The uterus and ovaries were removed after stunning and examined macroscopically, registering the ovarian cysts in diseased animals and follicles and corpus luteum in control animals to ensure the diagnosis. Tissue specimens (walls of uterus, cervix ( portio vaginalis cervicis) and ovaries) were packed in foil, and frozen within 15 min of stunning, and stored in liquid nitrogen before receptor analyses. Additional blood samples for steroid hormone and SHBG determinations were collect- ed from cows diagnosed by rectal palpation as animals with ovarian cystic disease. Serum was separated by centrifugation from blood samples and stored at $-20^{\circ} \mathrm{C}$ before steroid hormone assays.

Measurement of cytosol estrogen and progesterone receptor concentrations

In this report, cytosol receptors refer to those found in the cytosol fraction following homogenization of the tissue in buffer and ultracentrifugation of the homogenate.

Endometrium and myometrium were separated from frozen tissue specimens using a scalpel. Endometrial samples were scraped from the surface of the endometrium with a scalpel. Myometrial samples were cut from the middle stratum of the uterine wall. Macroscopically-selected stromal tissue was used in ovarian steroid receptor assays. The corpus luteum, follicles with their walls and the ovarian capsule were removed from specimens before assay.

Measurement of cytosol estrogen and progesterone receptor concentrations was performed as described previously (Vesanen et al. 1988). Briefly, tissue pieces were weighed, minced and homogenized in TETMO $10 \mathrm{G}$ buffer at $+4^{\circ} \mathrm{C}$. The homogenate was centrifuged and supernatants saved for receptor and protein assays. In estrogen receptor assays, the cytosol was incubated with various concentrations $(0.3-10 \mathrm{nmol} / \mathrm{l})$ of $\left[{ }^{3} \mathrm{H}\right]$ estradiol. Non-labeled testosterone was used to eliminate possible interference by serum proteins. Non-specific binding of $\left[{ }^{3} \mathrm{H}\right]$ estradiol was estimated by using a 200 -fold molar excess of non-labeled estradiol in parallel incubations. After incubation, non-bound steroids were separated by the use of dextran-coated charcoal and radioactivity was counted in a liquid scintillation counter. In the assay of cytosol progesterone receptor, cytosol was incubated with various concentrations $(0.4-14 \mathrm{nmol} / \mathrm{l})$ of $\left[{ }^{3} \mathrm{H}\right] \mathrm{ORG} 2058$. To estimate non-specific bind- 
ing of $\left[{ }^{3} \mathrm{H}\right] \mathrm{ORG} 2058$, a 200 -fold molar excess of non-labeled ORG 2058 was used in parallel incubations. The intra-assay coefficients of variation were $2 \%$ and $4 \%$ for ERC and PRC assays. The corresponding values for interassay coefficients of variation were $10 \%$ and $9 \%$, respectively.

\section{Measurement of steroid hormone and SHBG con- centrations}

Measurement of serum pregnenolone, progesterone, testosterone and 5 $\alpha$-DHT concentrations was performed by individual radioimmunoassays after solvent extraction and chromatographic purification of samples as described previously (Apter et al. 1976, Hammond et al. 1978, Leinonen 1980, Bolton et al. 1985). Briefly, unconjugated steroids were extracted from $2 \mathrm{ml}$ of serum and then fractionated on Lipidex $5000^{\mathrm{TM}}$ microcolumns (Packard - Becker B.V., Chemical Operations, Netherland), followed by radioimmunoassay of each steroid from the appropriate fraction using antisera of defined specificity (Jänne et al. 1974, Apter et al. 1976). The chromatographic fractionations of estrone $\left(E_{1}\right)$ and estradiol-17ß $\left(E_{2}\right)$, extracted from separate serum specimens, were performed as described by Leinonen (1980). The radioimmunoassays of $E_{1}$ and $E_{2}$ were performed as described previously (Vesanen et al. 1990).

The serum concentrations of bovine SHBG were determined in binding assays employing $\left[{ }^{3} \mathrm{H}\right] 5 \alpha$-DHT, as described previously (Hammond \& Lähteenmäki 1983, Vesanen et al. 1990).

In this report, cows with cystic ovarian disease were defined as those with serum progesterone concentrations below $2.7 \mathrm{nmol} / \mathrm{l}$. In addition, large (diameter $\geq 2.5 \mathrm{~cm}$ ) anovulatory follicular cysts were detected by rectal palpations and in macroscopical examinations after slaughter in 1 or both ovaries. In our previous studies (Vesanen et al. 1990, Vesanen et al. 1991) we investigated serum steroid hormone and SHBG con- centrations, and ERC and PRC contents of bovine genitalia in cows in normal physiological states. In this paper, those results are used as reference data (control animals referred to later in this text).

\section{Other methods}

Statistical comparisons of the results were performed by one-way analysis of variance and $t$ statistics by the Bonferroni method (Wallenstein et al. 1980). Linear regression analysis was used to evaluate the correlations.

\section{Results}

Control animals were divided according to serum progesterone concentrations into 2 groups. Group 1 (low progesterone) consisted of cows having serum progesterone concentrations below $2.7 \mathrm{nmol} / 1$, which corresponds to a progesterone concentration of $10 \mathrm{nmol} / \mathrm{l}$ in residual milk, the limit used in our previous studies (Vesanen et al. 1988, Vesanen et al. 1990, Vesanen et al. 1991). The second group (high progesterone) comprised animals with serum progesterone concentrations over $2.7 \mathrm{nmol} / \mathrm{l}$.

Bovine uterine cytosol ERC and PRC concentrations were measured simultaneously in endometrium and myometrium from cows with cystic ovarian disease. ERC contents in the endometrium were $550 \pm 297$ (mean \pm S.D., $\mathrm{n}=13$ ) $\mathrm{fmol} / \mathrm{mg}$ cytosol protein (c.p.) and in myometrium $405 \pm 273(n=13)$. In control animals (low progesterone), ERC concentrations were lower both in endometrium $(291 \pm 257 \mathrm{fmol} / \mathrm{mg}$ c.p., $\mathrm{n}=24, \mathrm{p}<0.01)$ and in myometrium $(237 \pm 164$, $\mathrm{n}=24, \mathrm{p}<0.05)$ than in cows with cystic ovarian disease. The differences in ERC contents were more remarkable $(\mathrm{p}<0.001)$ between cows with cystic ovarian disease and control animals with high progesterone (in endometrium $168 \pm 78$, $\mathrm{n}=22$ and in myometrium $134 \pm 82, \mathrm{n}=22$ ). ERC concentrations in the endometrium and myometrium correlated significantly ( $\mathrm{p}<0.01$, Fig. 1$)$ in 


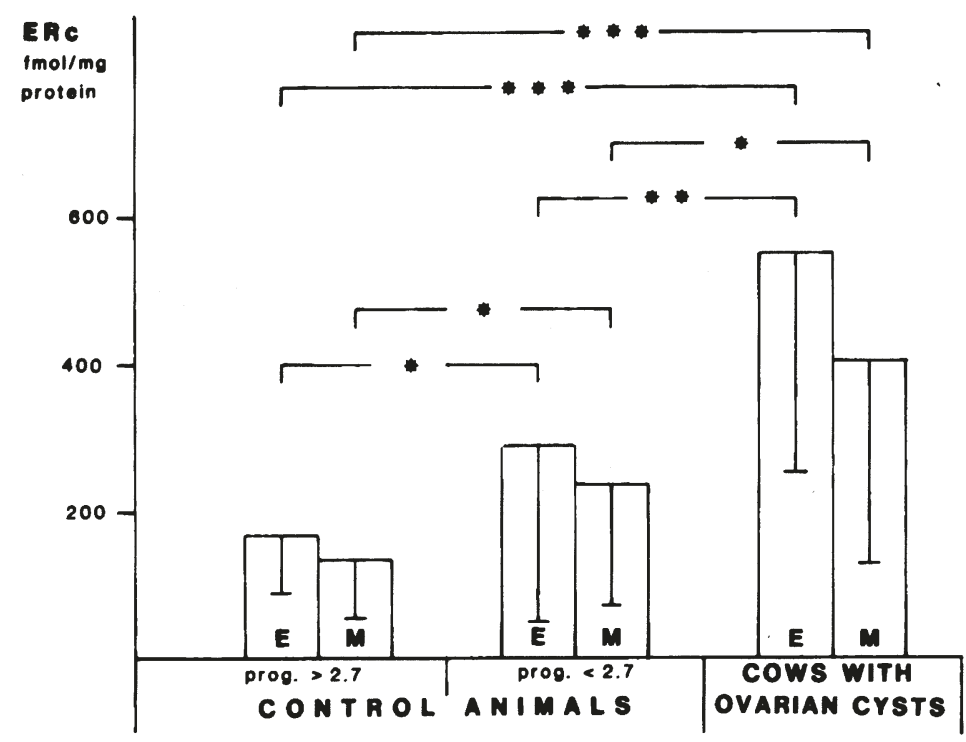

Figure 1. Bovine endometrial (E) and myometrial (M) cytosol estrogen receptor (ERC) concentrations (fmol/mg cytosol protein; mean and S.D.) in normal control animals when serum progesterone (prog.) concentration was $>2.7 \mathrm{nmol} / \mathrm{l}$ (number of animals, $\mathrm{n}=22$ ) or $<2.7 \mathrm{nmol} / \mathrm{l}(\mathrm{n}=24)$, and in cows with ovarian cysts (prog. $<2.7 \mathrm{nmol} / \mathrm{l}, \mathrm{n}=13)$. Significances: ${ }^{*} \mathrm{p}<0.05,{ }^{* *} \mathrm{p}<0.01,{ }^{* * *} \mathrm{p}<0.001$.

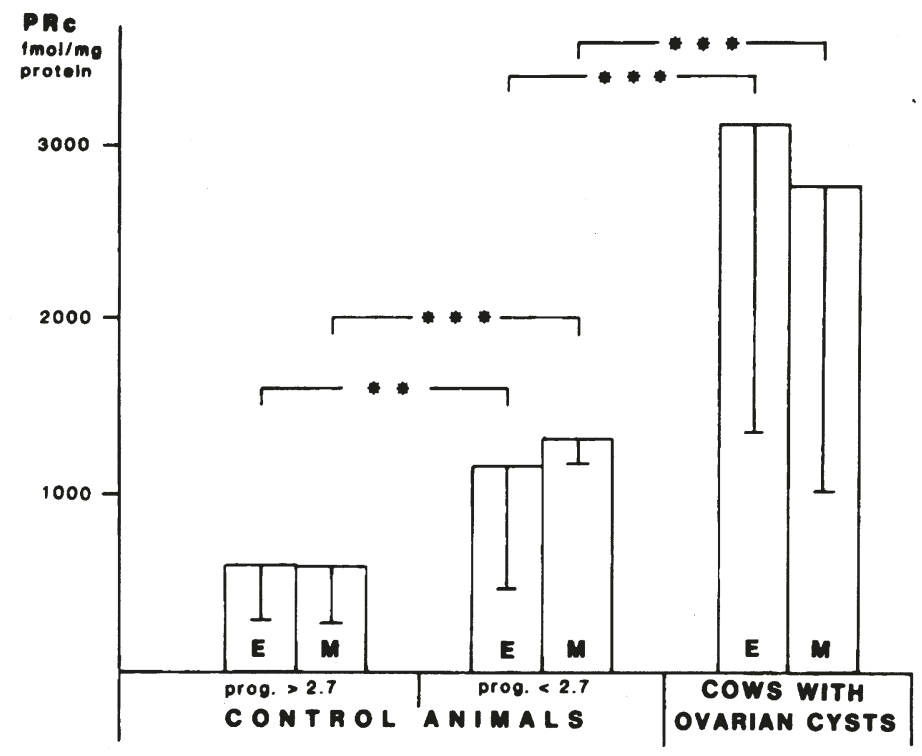

Figure 2. Bovine endometrial (E) and myometrial (M) cytosol progesterone receptor (PRC) concentrations in normal cows (control animals) and in cows with ovarian cysts. For other details see text to Fig. 1. 
individual cows with ovarian cysts. The same was observed concerning PRC contents of the endometrium and myometrium ( $p<0.05$, Fig. 2 ). The 2 control groups differed $(\mathrm{p}<0.05)$ in ERC concentrations both in endometrium and in myometrium (Fig. 1).

A disparity of PRC concentrations between animals with cystic ovarian disease and control animals was distinct. Endometrial PRC contents ( $3115 \pm 1760 \mathrm{fmol} / \mathrm{mg}$ c.p., $\mathrm{n}=13$ ) were considerably higher $(\mathrm{p}<0.001)$ in diseased animals than in control animals with low serum progesterone (endometrial PRC was $1162 \pm 692 \mathrm{fmol} / \mathrm{mg} \mathrm{c.p.,}$ $\mathrm{n}=24$ ) or high serum progesterone concentrations (endometrial PRC was 602 $\pm 309, n=22$ ). In cystic ovarian disease, myometrial PRC concentrations $(2761 \pm 1730 \mathrm{fmol} / \mathrm{mg}$ c.p., $\mathrm{n}=13)$ were also significantly higher $(\mathrm{p}<0.001)$ than those observed in control cows when serum progesterone was low (PRC was $1315 \pm 136 \mathrm{fmol} / \mathrm{mg}$ c.p., $\mathrm{n}=24$ ) or high (PRC was 599 $\pm 325, \mathrm{n}=22$, Fig. 2).

Bovine ERC and PRC concentrations in the uterine cervix and ovaries were variable and the receptor contents were considerably lower than those in endometrium and myometrium. The results are shown in Table 1.

In cows with cystic ovarian disease, the mean serum progesterone concentration ( $\mathrm{nmol} / \mathrm{l}$; mean \pm S.D.) of $0.51 \pm 0.37, n=27$ was not significantly different from those observed during postpartum anestrus $(0.34 \pm 0.42, \mathrm{n}=29)$ or in the follicular phase $(0.65 \pm 0.50, n=30)$ of the estrous cycle. Estradiol- $17 ß$ concentrations, on the other hand, were higher $(\mathrm{p}<0.001)$ in diseased cows $(29.7 \pm 13.2, n=25)$ than in control animals (at postpartum anestrus $17.6 \pm 5.9, \mathrm{n}=29$; in the luteal phase $14.7 \pm 5.5, \mathrm{n}=25$; in the follicular phase $16.2 \pm 7.4, n=30$ ) in various physiological

Table 1. ERC and PRC concentrations (fmol/mg cytosol protein; mean \pm S.D.) in bovine uterine cervix (portio vaginalis) and ovaries in normal control animals (serum progesterone concentration either below $2.7 \mathrm{nmol} / \mathrm{l}$ or over $2.7 \mathrm{nmol} / \mathrm{l}$ ) and in cows with cystic ovarian disease (serum progesterone concentration below $2.7 \mathrm{nmol} / \mathrm{l}$ ).

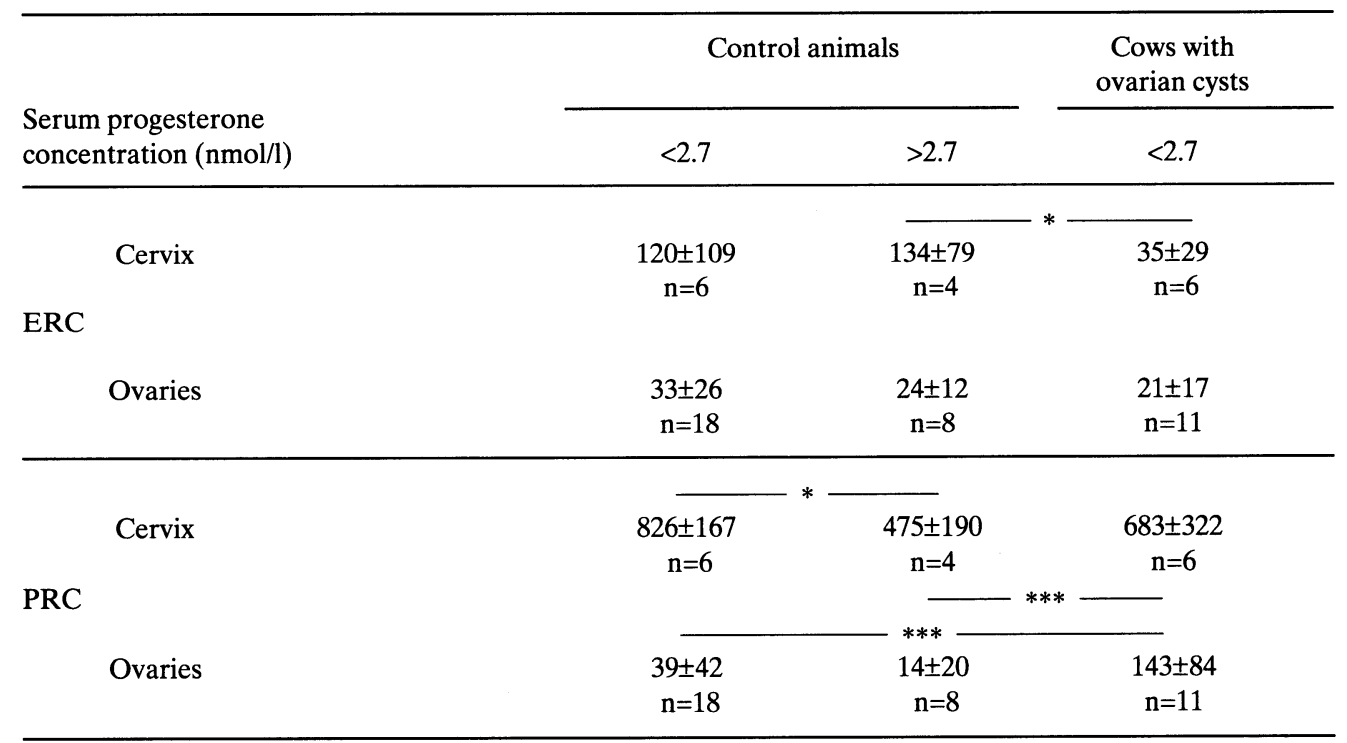

Significance levels: ${ }^{*} \mathrm{p}<0.05,{ }^{* * *} \mathrm{p}<0.001$ 
Table 2. Bovine serum steroid hormone and sex hormone-binding globulin (SHBG) concentrations (mean \pm S.D.) in control animals at various physiological states (at postpartum anestrus, during luteal and follicular phases of estrous cycle) and in cows with cystic ovarian disease.

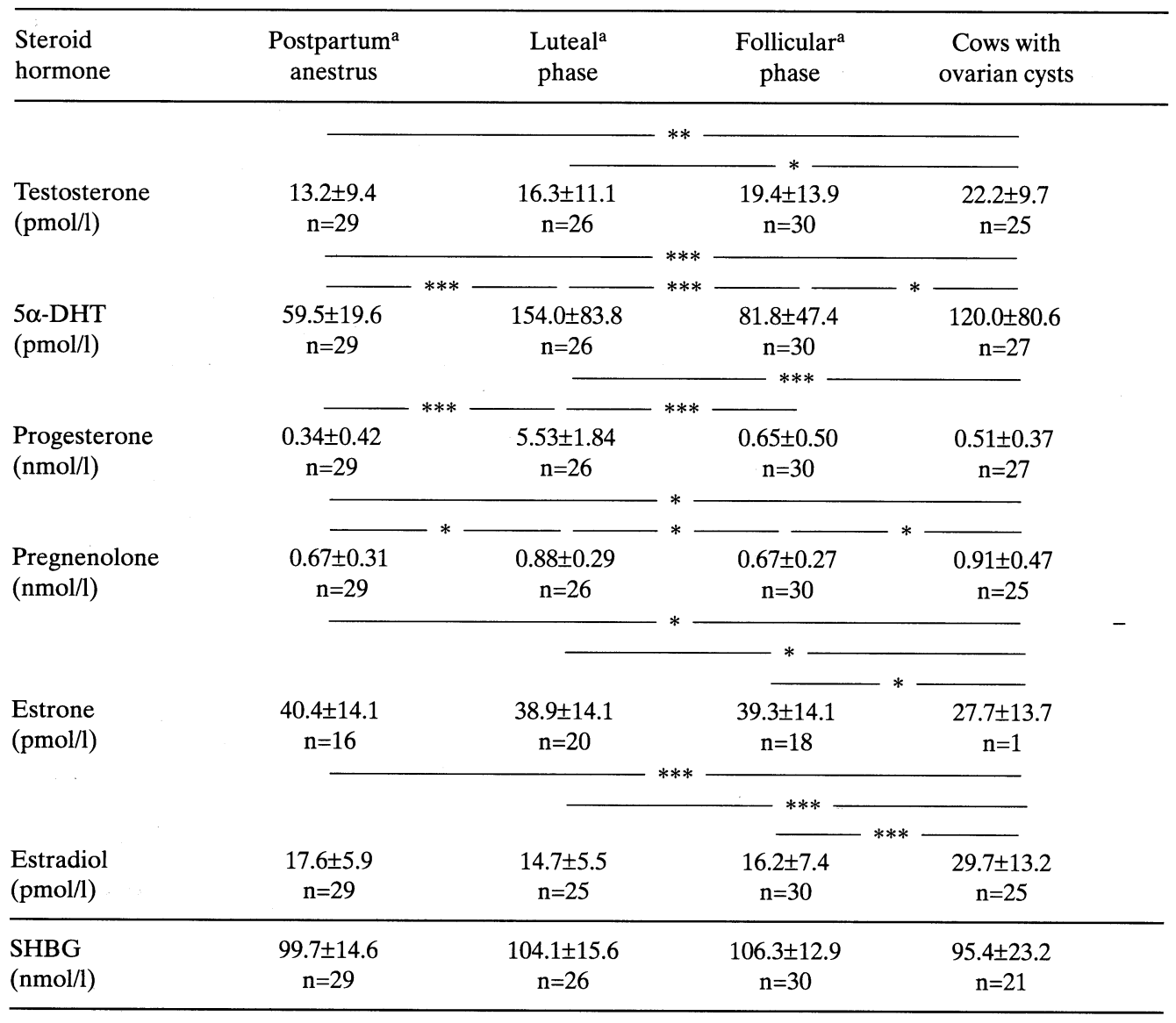

Significances: ${ }^{*} \mathrm{p}<0.05,{ }^{* *} \mathrm{p}<0.01,{ }^{* * *} \mathrm{p}<0.001$

$\mathrm{n}=$ number of samples

${ }^{\mathrm{a} C}$ Control data from Vesanen et al. (1990)

states (Table 2). Bovine serum SHBG concentrations $(95.4 \pm 23.2 \mathrm{nmol} / \mathrm{l}, \mathrm{n}=21)$ in cows with ovarian cystic disease were similar to those observed previously in normal animals (Vesanen et al. 1990).

\section{Discussion}

In our previous study, (Vesanen et al. 1991) we reported that when progesterone concentrations in bovine serum were low, both ERC and PRC concentrations in various regions of the uterus were higher than those observed during larger endogenous progesterone production. Thus, elevated uterine ERC and PRC concentrations in bovine cystic ovarian disease were expected. However, PRC concentrations in 
particular,in diseased animals, were obviously higher than concentrations in control animals when serum progesterone concentrations were low. The explanation for this could be connected to long-term low endogenous progesterone concentrations. Another reason is elevated E2 concentrations in the serum of diseased animals. In several animal models it has been observed that estradiol is associated with increased estrogen and progesterone receptor concentrations, while progesterone is associated with decreased concentrations of both estrogen and progesterone receptors (Katzenellenbogen 1980, Leavitt et al. 1983, Clark et al. 1985). On the other hand, bovine serum $\mathrm{E}_{2}$ concentrations are minimal (Vesanen et al. 1990) compared with those in human serum measured by the same methods. Hence, the main reason for the increased steroid hormone receptor contents in the uterus of cows with cystic ovarian disease appears to be long-term low endogenous progesterone concentrations together with elevated serum concentrations of $\mathrm{E}_{2}$.

In bovine cystic ovarian disease, steroid receptor concentrations did not differ significantly when endometrium and myometrium were compared. This finding is in agreement with our previous observation in cows with normal reproductive performances (Vesanen et al. 1991) that bovine endometrial and myometrial ERC and PRC levels are regulated similarly. In harmony with that, Kontula (1975), working with sheep uterine tissues, and Gorodeski et al. (1987), working with human uterus, reported that PRC concentrations were similar in the endometrium and the myometrium, in both the proliferative and early luteal phases. Although endometrial and myometrial cells are histologically different, steroid receptor (ERC and PRC) concentrations react similarly to endogenous steroid hormone stimulus in both normal and pathological conditions.

Bovine cervical and ovarian ERC and PRC concentrations were variable and clearly lower than those in the endometrium and myometrium in cystic ovarian disease. The human cervix is reported to contain PRC (Gorodeski et al. 1987), but the concentrations are lower than in bovine cervix (Vesanen et al. 1991). On the other hand, human (Vierikko et al. 1983) and bovine (Vesanen et al. 1991) ovarian ERC and PRC concentrations are all low. Thus, disturbances in bovine steroid hormone modes of action and the absence of the influence of normal cyclic progesterone production, can most clearly be seen in altered ERC and PRC concentrations in the endometrium and myometrium. In the present study, cows with cystic ovarian disease have been limited to those with serum progesterone concentrations below $2.7 \mathrm{nmol} / \mathrm{l}$. In other words, cows with luteal cysts and thereby elevated progesterone concentrations were excluded from this study. Hence, the mean serum progesterone concentration was at basal level (as during postpartum anestrus and in the follicular phase of the estrous cycle) in cystic cows. In the cows with ovarian cysts, $5 \alpha$-DHT, as well as pregnenolone concentrations were slighly elevated as during luteal phase of estrous cycle (Vesanen et al. 1990). This may be caused by the changes of steroidogenesis of the ovarian tissue. Serum estradiol-17ß concentrations were more clearly elevated in diseased animals compared to control cows. In previous investigations on bovine cystic ovarian disease, $\mathrm{E}_{2}$ concentrations have been reported to be variable (Kesler et al. 1980), either higher (Kittok et al. 1974, Cantley et al. 1975) or not different (Garverick et al. 1976, Kesler et al. 1978) from those observed in normal animals.

As conclusion, features of bovine ERC and PRC concentrations are that they share their responsiveness to endogenous progesterone with many mammalian species. The present findings demonstrate that, long-term low serum progesterone concentrations, together with ele- 
vated concentrations of serum estradiol-17ß, are associated with marked elevations of ERC and PRC concentrations in bovine endometrium and myometrium.

\section{Acknowledgements}

This study was supported by grants from the Research Council for Medicine, and the Research Council for Agriculture and Forestry, of the Academy of Finland, the Oscar Öflund Foundation, the Finnish Veterinary Science Foundation and Coopers Information Center.

\section{References}

Apter D, Jänne O, Karvonen P, Vihko R: Simultaneous determination of five sex hormones in human serum by radioimmunoassay after chromatography on Lipidex-5000. Clin. Chem. 1976, 22, 32-38.

Ax R, Bellen M, Schneider D, Haase-Hardie J: Reproductive Performance of Dairy Cows with Cystic Ovaries Following Administration of Procys$\operatorname{tin}^{\mathrm{TM} 1}$. J. Dairy Sci. 1986, 69, 542-545.

Bolton N, Ruokonen A, Vihko R: Stimulation of the synthesis of steroids and steroid sulphates in human testicular tissue in vitro by $\mathrm{HCG}$ and by 8 bromo-cyclic AMP. J. Biochem. 1985, 22, 481-485.

Brown J, Schoenemann H, Reeves J: Effect of FSH treatment on LH and FSH receptors in chronic cysticovarian-diseased dairy cows. J. Anim. Sci. 1986, 62, 1063-1071.

Bäckström G, Edqvist L-E, Ekman L, Gustafsson B: Effect of LH- RH in cows with cystic ovaries: evaluation of a field study. Proc. 8th Int. Congr. on Anim. Reprod. A.I. 1976, 4, 548-551.

Cantley T, Garverick H, Bierschwal C, Martin C, Youngquist $R$ : Hormonal response of dairy cows with ovarian cysts to GnRH. J. Anim. Sci. 1975, 41, 1666-1673.

Clark J, Scrader W, $O{ }^{\prime}$ Malley B: Mechanisms of steroid hormone action. In: Witson J, Fortec D (eds): Textbook of Endocrinology. W.B.Saunders Company, Philadelphia, 1985, 33-75.

Dobson H, Rankin J, Ward W: Bovine cystic ovarian disease: Plasma hormone concentrations and treatment. Vet. Rec. 1977, 3, 459-461.

Garverick H, Kesler D, Cantley T, Elmore R, Youngquist $R$, Bierschwal C: Hormone response of dairy cows with ovarian cysts after treatment with HCG or GnRH. Theriogenology 1976, 6, 413-425.

Gorodeski I, Geier A, Lunenfeld B, Beery B, Bahary
$C$ : Progesterone $(\mathrm{P})$ receptor dynamics in estrogen primed normal human cervix following $\mathrm{P}$ injection. Fertil. Steril. 1987, 47, 108-113.

Hammond $G$, Ahonen $V$, Vihko R: The radioimmunoassay of testosterone, $5 \alpha$-dihydrotestosterone and their precursors in the human testis. J. Androl. (suppl.) 1978, 2, 391-399.

Hammond GL, Lähteenmäki PLA: A versatile method for the determination of serum cortisol binding globulin and sex hormone binding globulin binding capacities. Clin. Chim. Acta 1983, 132, 101-110.

Jänne O, Apter D, Vihko R: Assay of testosterone, progesterone and $17 \alpha$-hydroxyprogesterone in human plasma by radioimmunoassay after separation on hydroxyalkoxypropyl Sephadex. J. Steroid Biochem. 1974, 5, 155-162.

Katzenellenbogen B: Dynamics of steroid hormone action. Annu. Rev. Physiol. 1980, 42, 17-35.

Kesler D, Garverick H, Caudle A, Bierschwal C, Elmore R, Youngquist R: Clinical and endocrine responses of dairy cows with ovarian cysts to GnRH and PGF ${ }_{2 \alpha}$. J. Anim. Sci. 1978, 46, 719-725.

Kesler D, Garverick H, Caudle A, Elmore R, Youngquist $R$, Bierschwal $C$ : Reproductive hormone and ovarian changes in cows with ovarian cysts. J. Dairy Sci. 1980, 63, 166-170.

Kesler DJ, Garverick HA: Ovarian cysts in dairy cattle: a review. J. Anim. Sci. 1982, 55, 1147-1159.

Kittok R, Britt J, Edgerton L: Serum steroid after gonadotropin treatment in cows with ovarian follicular cysts. Amer. J. vet. Res. 1974, 35, 15751576.

Kontula K: Progesterone-binding proteins from endometrium and myometrium of sheep uterus: a comparative study. Acta Endocr. (Kbh.) 1975, 78, 593603.

Koppinen J, Vesanen M, Alanko M: Ovarian cysts in dairy cattle - some aspects of diagnosis, treatment with GnRH and HCG and subsequent milk progesterone values. Nord. Vet.-Med. 1984, 36, 26-31

Leavitt W, MacDonald R, Okulicz W: Hormonal regulation of estrogen and progesterone receptor systems. In: Litwack G (ed): Biochemical Actions of Hormones. Academic Press, New York, 1983, 32-356.

Leinonen $P$ : Estrone and estradiol concentrations in the testis and spermatic and peripheral venous blood of elderly men: the influence of estrogen treatment. J. Steroid Biochem. 1980, 13, 737-742.

Wallenstein S, Zucker C, Fleiss J: Some statistical methods useful in circulation research. Circ. Res. $1980,47,1-9$. 
Vesanen M, Isomaa V, Alanko M, Vihko R: Cytosol estrogen and progesterone receptors in bovine endometrium after uterine involution postpartum and in the estrous cycle. Anim. Reprod. Sci. 1988, 17, 920.

Vesanen M, Isomaa V, Bolton N, Alanko M, Vihko R: Bovine steroid hormone and SHBG concentrations postpartum and during the oestrous cycle. Acta vet. scand. 1990, 31, 459-469.

Vesanen M, Isomaa V, Alanko M, Vihko R: Bovine uterine, cervical and ovarian estrogen and progesterone receptor concentrations. Anim. Reprod. Sci. 1991, 26, 61-71.

Vierikko P, Kauppila A, Vihko R: Cytosol and nuclear estrogen and progestin receptors and 17-betahydroxysteroid dehydrogenase activity in nondiseased tissue and in benign and malignant tumors of the human ovary. Int. J. Cancer 1983, 32, 413422.

\section{Sammanfattning}

Koncentrationerna av cytoplasmiska estrogen- och progesteronreceptorer i livmodern, livmoderhalsen och ovarierna hos kor med cystiska ovarier.

Koncentrationerna i livmodern av cytoplasmiska estrogen- (ERC) och progesteronreceptorer (PRC) hos kor med cystiska ovarier och normala kor jämfördes. Både ERC och PRC koncentrationerna fanns vara högre hos kor med cystiska ovarier än hos normala kor vars blodserum progesteronhalt var låg $(<2.7 \mathrm{nmol} / \mathrm{l})$. Skillnaderna i receptorkoncentrationerna var märkbart större då kontrollkornas progesteronhalt var hög ( $>2.7$ $\mathrm{nmol} / \mathrm{l})$. Däremot fann man inga skillnader då man jämförde endometrium- och myometriumkoncentrationerna av ERC och PRC hos kor med cystiska ovarier med motsvarande hos de bägge kontrollgrupperna. ERC- och PRC-koncentrationerna i cervix och ovarier var på märkbart lägre nivå än i livmodern. Korna med cystiska ovarier hade en högre blodserum estradiolhalt än kontrollkorna. Orsaken till ökningen av receptorkoncentrationerna anses vara en längre inverkan av en låg progesteronnivå kombinerad med en ökad estradiolhalt i serumet.

(Received November 30, 1991; Accepted October 9, 1992).

Reprints may be requested from: M. Vesanen, Department of Clinical Chemistry, University of Oulu, Kajaanintie 50, SF- 90220 Oulu, Finland. 
